\title{
A GÊNESE DA DOCÊNCIA UNIVERSITÁRIA
}

THE GENESIS OF UNIVERSITY TEACHING

LA GENESE DE L'ENSEIGNEMENT UNIVERSITAIRE

LA GÉNESIS DE LA DOCENCIA UNIVERSITARIA

Ildeu Moreira Coêlho *

\section{RESUMO}

$O$ artigo discute a constituição da docência, no medievo latino, inseparável das transformaçôes socioeconômicas e políticas, das transferências do saber greco-árabe, dos renascimentos cultural e escolar, do trabalho de monges copistas e tradutores, da ligação intrínseca entre investigação, formação e ensino na universidade recém-criada. Recuperando etimologia e pronúncia ${ }^{* *}$ dos termos, discute a Escolástica, filosofia e método de ensino em que a docência se afirma no ato de ler, explicar, comentar os textos, submeter conceitos, argumentos e teses ao crivo da razão, pôr questōes em discussões públicas nas quais a verdade não depende da autoridade de quem diz, mas daquilo que foi dito. Redescobertas e traduzidas, as obras de Aristóteles surgem como ameaça para alguns mestres, mas para outros era tudo o que precisavam para exercer seu oficio: um texto lógico, profundamente formativo. Assim, a universidade medieval e seus mestres podem nos ajudar a repensar e recriar a docência hoje.

Palavras-chave: Docência. Copistas. Tradutores. Transferências do saber. Autoridade. Razão.

* Doutor em Filosofia pela Universidade de São Paulo (1978). Professor do Programa de Pós-Graduação e Cursos de Graduação da Faculdade de Educação da Universidade Federal de Goiás (ildeuc@terra.com.br).

** Em caso de dúvida, o leitor poderá consultar, ao final do artigo, a pronúncia correta de termos latinos e gregos. 
Vivemos numa época em que valores e formas de existência pessoal e social parecem perder sua razão de ser, bem como a natureza, a estrutura e o destino de instituições historicamente consagradas são postos em questão pelo Estado, pela mídia, pelos donos do poder e do dinheiro; em que o sentido e as formas da educação, da escola, da universidade e da docência são desqualificados em nome das transformações decorrentes dos avanços da ciência e da tecnologia; em que as universidades federais são ajustadas e azeitadas, a um preço que parece ouro, mas que depois pode revelar-se moeda de ferro, para que, com presteza, agilidade e eficiência, respondam positivamente ao que o Estado lhes impõe como se fosse sua redenção e necessária adequação às novas e inescapáveis exigências da sociedade, num mundo que, com doce encanto, pompa e empáfia, se autoproclama globalizado.

Nesses momentos, sobretudo, é preciso manter viva e fecunda a interrogação sobre a natureza e o sentido da universidade, do trabalho intelectual, da investigação científica e filosófica, do ensino de graduação e de pós-graduação, da docência, da aula, que conferem razão de ser à universidade como instituição social. Caso contrário, em nome de acompanhar as transformações próprias do mundo tecnológico, de preservar as condiçôes de falar e de educar as novas geraçōes, corremos o risco de imaginar que não temos outra alternativa senão a de aceitar acriticamente as políticas educacionais dadas e incorporar as novas tecnologias aos processos de ensinar e aprender. Seria isso o que nos resta da universidade, desde seu surgimento e afirmação como corporação de ofício, instituição social, na Idade Média latina, e do trabalho intelectual, da docência e da sonhada, e em geral não verdadeiramente assumida, autonomia universitária?

O empobrecimento, a simplificação e a banalização dessas realidades negam seu sentido e seus vínculos intrínsecos com a sociedade, as obras de cultura, a criação e a formação, que não se reduz à profissionalização, ao preparo para o mundo do trabalho, do mercado, do sucesso, no qual os universitários podem ser diferentes uns dos outros e ao mesmo tempo capazes de defender e afirmar interesses e privilégios da minoria, deixando a maioria, os outros, onde sempre estiveram. E muitas vezes o ensino superior, a universidade, faz e legitima tudo isso, apesar das disciplinas e práticas pretensamente lúcidas, críticas e comprometidas com a autonomia, a liberdade e a justiça. Assim, nestes dias de nebulosidade, de terra movediça e escorregadia, corremos o risco de perder a lucidez e a dignidade, das quais jamais podemos abrir mão sem negar a universidade como instituição social cujo sentido, desde sua criação, consiste no trabalho intelectual rigoroso, voltado para o equacionamento dos problemas postos pela manifestação da cultura como saber racional.

Ao se tornar demonstrativo, forma específica de apreensão e explicação da natureza, do ser mesmo do mundo das coisas e dos homens, no contexto histórico e sociocultural da Grécia a partir do século VI a.C., o saber põe o problema de seu sentido e de sua transmissão, define suas regras, normas, exigências e implicações no que diz respeito à comunicação social de uma cultura do lógos, da razão, em sua exigência de universalidade 
e de realização da areté, da excelência. $\mathrm{Na}$ interessante polêmica sobre o ato de ensinar, diferentemente dos sofistas, Sócrates propõe o ideal de vida conforme a razão, bios theoretikós, vida teorética, consagrada ao cultivo do pensamento, bem como uma nova forma de existência pessoal e coletiva, uma autêntica conversão ao mundo do espírito, da perfeição, da incansável busca da verdade e do bem. Embora jamais tenha se apresentado como mestre nem reconhecido alguém como seu discípulo e não tenha elaborado doutrina, afirmando, em várias ocasiōes, não ter ensinado a ninguém saber algum, sempre se colocou à disposição dos que quisessem ouvi-lo e com ele conversar. Ao oferecer-lhes a possibilidade da convivência, interroga-os procurando ajudá-los a superarem a esfera da opinião, do imediato, do sensível, do particular, dos interesses, e a se elevarem ao plano do saber verdadeiro, do universal, do bem comum.

Sem dúvida, do ponto de vista metodológico e formativo, a investigação socrática permanentemente se retoma por meio de perguntas e respostas no sentido de chegar a uma definição, sem jamais fechar os olhos às aporias que possam emergir no movimento de constituição do pensamento. Num diálogo aberto que envolve mestre e discípulo no confronto de idéias, conceitos e argumentos, Sócrates se dirige a um interlocutor singular e num diálogo a dois, sem nenhuma verdade a transmitir-lhe, assume como inerente a seu modo dialético de conversar o "princípio de que jamais se deve admitir como verdadeiro senão aquilo a que o outro dá formalmente seu acordo" (WOLFF, 1993, p. 131). E então interroga seu interlocutor, refutando a resposta dada, mostrando-lhe que, embora considerada inicialmente verdadeira, ela contradiz outras afirmações fundamentais às quais ele não pode negar sua concordância.

Sem impor uma verdade prévia e exterior à discussão em curso, o diálogo submete à prova a coerência interna das respostas livremente dadas e assumidas como verdadeiras pelo interlocutor. Ao longo desse processo de purificação e de elevação intelectual, o diálogo liberta o interlocutor da esfera da aparência, da opinião, dóksa, dos negócios e dos resultados, dispondo-o para pôr-se a serviço da verdade, seguindo as exigências da demonstração dialética, da ciência, epistéme, da teoria e suas implicações na esfera da ação, da elevação do homem ao sumo bem.

E assim, com Sócrates e em sua esteira com Platão e Aristóteles, a filosofia grega, em sua especificidade histórica, se realiza e se afirma como elevação ao plano das Idéias, do ser e da essência, como formação, conversão do homem à racionalidade no pensar e no agir. Desde então "o caminho da razão desenrola-se na direção apontada pelas primeiras tentativas gregas de traçar um roteiro - um méthodos - em que invenção e organização do saber racional se conjugassem e permitissem ao problema da sua comunicação social tornar-se também um problema de razão: de técnica de ensinar, de progressiva paideia, em suma, da posse e do gozo de uma cultura superior, que confere habilidade, prestígio e uma mais alta realização humana" (VAZ, 1966, p. 16), compreendida como busca da universalidade pela compreensão e comunicação de sentido, abertura à dimensão do 
outro, do social, da autonomia, do autós nómos, à superação da contingência e da particularidade do mundo das coisas, dos animais e do próprio homem. A esse problema, num momento de profundas transformaçōes da Idade Média latina, em que a cultura se abre ao universal, a universidade é chamada a responder, de forma institucional e amadurecida.

O surgimento da associação de mestres e escolares, universitas magistrorum et scholarium, chamada depois apenas universitas, foi um acontecimento decisivo no movimento de criação, cultivo e transmissão do saber no apogeu da cultura e da civilização medieval. O termo universitas, usado pelos romanos para significar universalidade, totalidade, conjunto de coisas ou de pessoas, associação, na Idade Média não se refere inicialmente ao conjunto de Faculdades reunidas sob uma estrutura uniforme de organização e de poder, mas à corporação de mestres e escolares dedicados ao estudo das artes (filosofia), da teologia, do direito e da medicina, que se reúnem, garantidos por estatutos próprios, para se proteger das ameaças dos poderes locais, regulamentar e garantir o exercício autônomo do ofício de investigar e de ensinar. Como corporação dos que buscam e ensinam o saber, a universidade foi antecedida e acompanhada por significativas mudanças socioeconômicas, culturais e políticas, pelo expressivo aumento da população urbana e transformação das cidades, pelo trabalho de copistas, de tradutores e pelo movimento de transferências de saber, como ainda veremos, pelo aparecimento das comunas, que pôs a questão do poder em novos termos, pelo renascimento da cultura, dos estudos e da escola, que em algumas regiōes havia desaparecido com as invasões bárbaras, a ruralização de extensas regiōes antes urbanizadas e o lento desmoronar do Império Romano do Ocidente.

Com a expansão do cristianismo, o crescimento do número de batizados e o esmorecimento da fé, da piedade e da caridade próprias das primeiras comunidades de fiéis, alguns cristãos começam a afastar-se do mundo do dinheiro, do poder e do prazer, rumo ao deserto, para viverem em profundidade a ligação com Deus, a fé, no silêncio, na oração e na penitência. Aparece então no século III, no Oriente, o anacoreta, em grego anakhoretés, o que vive retirado, afastado; ou monge, aquele que vive só, em latim monachus. Na segunda metade do século IV surgem os monges no Ocidente, vivendo em comunidade o ideal de perfeição cristã, por meio dos votos de pobreza, castidade e obediência e da evangelização, o que exige conhecimento das questôes da fé e da cultura profana para poderem compreender, ensinar, propagar e defender a doutrina cristã. São chamados também de religiosos, porque procuram viver de forma plena a religião cristã, ou de regulares porque seguem as regras, em latim regulae, próprias de sua Ordem, instituição criada para a realização do sentido e dos fins da vida monástica.

Ao contrário dos mosteiros orientais, que, apesar das figuras ilustres de São Basílio (329/330-379) e São Jerônimo (340/350-419), se isolaram do mundo sem maiores preocupaçōes de se constituir como centros de estudo e de difusão cultural, no Ocidente 
os mosteiros, sobretudo os beneditinos, valorizavam a cultura letrada e abrigavam monges eruditos. Desde o início da vida monacal, nos primeiros séculos da Era Cristã, e no período de maior intensidade das invasóes bárbaras, a cultura se refugia nos mosteiros ocidentais, que promovem uma certa unidade cultural e realizam o trabalho fundamental de transcrição, preservação e difusão dos textos antigos.

Mas tudo isso talvez terá pouco ou nenhum sentido sem a compreensão da Idade Média como sociedade e civilização por excelência do livro, dos centros de estudo, do ensino e da aprendizagem do pensamento, que se constituiu e se afirmou num longo e significativo processo de transferência de saberes de uma época e de um lugar para outro, envolvendo impérios do Médio Oriente e do Ocidente, povos, civilizações, culturas, religiōes, sobretudo as religiōes do livro: a Torah dos judeus, a Bíblia dos cristãos e o Alcorão dos muçulmanos. Chamado de translatio studii ou translatio studiorum, esse movimento de translação da atividade intelectual, dos estudos, dos centros de estudo, de deslocamento de sábios, de filósofos, de troca de manuscritos e idéias envolve, além disso, deslocamento dos centros de poder, translatio imperii. $\mathrm{Na}$ verdade não é um movimento único e pontual, mas em sua unidade é também múltiplo. São transferências, passagens, translationes studiorum, no plural, com duração de aproximadamente mil anos, em tempos e lugares diferentes, que chegam à Idade Média latina, passando por rotas e caminhos variados, pelas mãos de sábios, estudiosos, comerciantes, conquistadores e guerreiros, junto com as espadas, a seda e as especiarias do Oriente, em especial de Bizâncio, Damasco, Bagdá e da Espanha islâmica.

A primeira translatio studii se inicia com o fechamento da escola filosófica de Atenas, fundada pelo neoplatônico Plutarco, entre o final do século IV e o início do século V, após o desaparecimento da Academia platônica com a destruição da cidade pelas tropas romanas comandadas por Silas, em 86 a.C. Esse fechamento foi uma decorrência do Edito de 529, ato político de Justiniano I, imperador em Constantinopla de 527 a 565, no sentido de "preservar" a unidade religiosa e assim manter, ou construir, a unidade do Império, e menos uma questão propriamente filosófica ou pedagógica. E então os filósofos neoplatônicos Damáscio, Diógenes, Eulâmio, Hérmias, Isidoro de Gaza, Prisciano da Lídia e Simplício abandonam Atenas, domínio do Império Romano do Oriente, rumo à corte persa do rei sassânida Cosroés I (531-579), admirador da cultura grega. Após curta permanência na corte, desiludidos por não encontrarem aí condições políticas semelhantes às pensadas n'A República de Platão, dirigem-se novamente aos domínios dos imperadores bizantinos, na cidade de Harran, segundo De Libera, "exemplo único de uma cidade dedicada à filosofia" (1998, p. 26). Nessa viagem de Atenas para a Pérsia (Irã) e daí a Harran, com eles foram os manuscritos, a filosofia e o domínio das línguas.

A Escola teológica de Edessa (atual Urfa, na Turquia), onde o nestorianismo condenado como heresia no Concílio de Éfeso, em 431, ainda contava com adeptos, foi fechada em 489 por Zenão, imperador em Constantinopla de 474 a 491. Os adeptos 
dessa heresia se refugiaram em Nísibe, na Pérsia, levando obras de Aristóteles e outros textos gregos, dando continuidade à difusão de sua interpretação teológica, assumida depois pela Igreja da Pérsia. Apesar de condenado como herético pelo Concílio de Calcedônia, em 451, e das perseguições, o monofisismo, ligado e em parte oposto ao nestorianismo, se expandiu sobretudo na Síria e no Egito desde as primeiras décadas do século VI. Em sua versão elaborada por Severo de Antioquia, foi assumido pelas "Igrejas dissidentes" sírias ou jacobitas, armênias, coptas e etíopes.

Essas polêmicas teológicas, desde os primeiros séculos do cristianismo e durante a Idade Média, são inseparáveis da filosofia e da ciência, a começar pela contribuição fundamental da lógica aristotélica e dos conceitos de razão, unidade, tempo, criação, indivíduo, pessoa, natureza, essência, ser, hipóstase, substância e acidente, entre outros. Suas implicaçôes se estendem além dos embates entre ortodoxia e heresia, das articulações do poder e das perseguições no interior da Igreja e do Império bizantino, levando as ciências e a filosofia a serem cultivadas à margem do poder central e da capital do Império comprometida com a ortodoxia, e em geral por cristãos nestorianos em Edessa e Nísibe, ou em Antioquia e Amida por cristãos monofisistas da Igreja da Síria, conhecidos como jacobitas. O siríaco surge, então, como uma importante língua de tradução de obras de filosofia e ciências, entre os séculos VII e IX e, no século X, tornase sobretudo uma língua de produção de comentários, commentarii, do verbo latino commentari, que significa ter em mente, relembrar, estudar, pensar, descobrir, comentar, escrever sobre um assunto. $\mathrm{O}$ comentário surge bem antes da Idade Média, à medida que a filosofia passa a ser ensinada em outras cidades e escolas, sem relação de continuidade com as antigas escolas de Atenas e seus sucessores, como a Academia de Platão e o Liceu de Aristóteles. O ensino assume, então, uma nova forma, a do comentário, da exegese e da explicação dos textos, numa tentativa de voltar às origens. "A mudança radical que se opera por volta do século I a.C. consiste no fato de que, doravante, é o próprio ensino de filosofia que, no essencial, toma a forma de um comentário de texto" (HADOT, 1999, p. 218).

Uma segunda transferência de manuscritos e saberes acontece de Alexandria para os mosteiros da Síria, nos séculos VII e VIII, seguindo as rotas dos cristãos hereges formados nos embates das primeiras aproximações entre a filosofia grega e a Bíblia, das sínteses iniciais entre filosofia e cristianismo e nos comentários dos neoplatônicos Filo, o hebreu, Amônio Sacas, o iniciador do neoplatonismo, e seu discípulo Plotino, Orígenes, o cristão, e João Filoponos. Ao conquistarem Alexandria e Síria em meados do século VII, os árabes encontram no neoplatonismo dos alexandrinos, que não dispensa a contribuição de Aristóteles, as fontes principais para a leitura e a elaboração dos comentários dos textos clássicos, e a constituição da filosofia no Islã oriental. Inicia-se, então, o movimento da terceira translatio studiorum, de Alexandria a Bagdá, da cultura siríaca à cultura árabe. Nos séculos VIII e IX a filosofia e a ciência já migraram para o Oriente islâmico, onde em 750 a família abássida, descendente de al-Abbas, tio do 
profeta Maomé (ca.570-632), assume o poder em Damasco e em 762 transfere o governo para Bagdá. No século X, recolhido, transcrito, traduzido, comentado e reelaborado, esse saber já se faz presente em boa parte do Oriente e em algumas regiōes do Ocidente, seguindo as rotas das incursôes políticas, militares e religiosas do Islã.

As translationes studiorum são movimentos históricos e socioculturais de translação de manuscritos, conhecimentos, filosofia e ciência, inseparáveis do persistente trabalho dos monges que os transcrevem, dos tradutores que vertem para o latim, a língua comum, obras em grego, siríaco ou árabe, bem como dos mestres e estudantes que, nas escolas abaciais, episcopais e sobretudo na universidade, lêem, comentam, põem em questão os textos e as afirmações e tudo submetem ao crivo da razão, em profundos e animados debates na universidade nascente, como veremos. Essas transferências são uma abertura ao olhar, à compreensão e à práksis da sociedade, da cultura e da civilização do outro, o reconhecimento e a afirmação de seu sentido e importância na constituição de nossa compreensão, pensamento, cultura e civilização.

A Ordem criada em 529 por Bento de Núrsia (ca. 480-ca. 547), fundador do Mosteiro de Monte Cassino, entre Roma e Nápoles, deu impulso à transcrição dos livros sagrados e profanos nas escrivaninhas, scriptoria, dos mosteiros, sem o que não conheceríamos o legado cultural dos gregos e romanos e em parte do Oriente, em termos de filosofia, política, ética, letras e artes, matemática, astronomia, medicina, direito e do que até meados do século XX se chamava história natural. Não teria sido possível o estudo das sete artes liberais, formadas pelo trivium (gramática, retórica e dialética ou lógica), que tinha por objeto a linguagem, e pelo quadrivium (aritmética, geometria, astronomia e música), que estudava o mundo das coisas; nem o florescimento cultural iniciado com Carlos Magno (742-814), rei dos francos (768-814) e imperador dos romanos (800-814), a grande expansão escolar dos séculos XI ao XIII, a criação da universidade, o Renascimento dos séculos XV e XVI. Enfim, o Ocidente não seria tal como hoje o vemos. Os ideais e as regras (534) da nova Ordem se expandem, ganham força e estarão na origem de várias outras ordens e de importantes reformas da vida monástica. Seu lema, ora et labora, resume o dia e a vida do monge em oração e trabalho, o que para muitos significa oração e estudo, trabalho de transcrição e tradução de textos.

Coroado na noite de Natal de 800 pelo papa Leão III, Carlos Magno aproxima-se de pessoas cultas, em especial do monge beneditino de elevada cultura, Alcuíno de York (730-804), a quem confia a direção da escola palatina (782-796), de palatium, em Aixla-Chapelle. Recomenda aos bispos e monges a criação de escolas, o cultivo e o ensino das belas letras. Apesar de uma preocupação reduzida praticamente ao mundo da palavra, e não das coisas, de seus modestos horizontes e resultados, sobretudo se comparados com o que acontecia, na mesma época, no Islã oriental, o chamado renascimento carolíngio, de Carlos Magno, Carolus, levou à formação de bibliotecas e a uma maior valorização dos manuscritos, que passaram a ser buscados, adquiridos, copiados, traduzidos, comentados. Aos poucos o Ocidente dirige seu olhar para os 
autores gregos e latinos, o que contribui para o florescimento cultural, a aculturação e o restabelecimento do convívio com o latim clássico, cada vez mais distante em virtude do quase desaparecimento da escola e das invasões bárbaras que começaram a chegar à região da atual Europa, trazendo outras culturas e línguas, antes mesmo da Era cristã.

Entre 750 e 1050, sobretudo no apogeu cultural e político do califado abássida de Harun al-Rachid (786-809), contemporâneo de Carlos Magno, o mundo islâmico vive profunda mudança cultural. Livros são buscados em países distantes, e cristãos incorporados ao trabalho de traduzir quase tudo para o siríaco e o árabe; os textos são lidos e comentados, numa aproximação da herança cultural da humanidade escrita em hebraico, siríaco, persa, hindu, latim e grego, no sentido de conhecê-la e de dar-lhe continuidade.

Em 711, Córdoba e Toledo, na Espanha, caem sob o poder das tropas de Tariq Ibn Ziyad, do califado omíada sediado em Damasco de 660 a 750. Em 712, novos invasores árabes conquistam Medina, Sevilha e Mérida. Em 755 chega à Espanha Abd al-Rahman I, último remanescente da dinastia omíada, destituída do poder pelos abássidas, vence as tropas do califa e instala o emirado de Córdoba, independente de Bagdá (abássidas) e sob seu poder até sua morte em 788. Governando de 912 a 961 o reino hispano-muçulmano da Andaluzia, com capital em Córdoba, Abd al-Rahman III se autoproclama califa em 929, sucessor do Profeta com poder político e autoridade religiosa, líder temporal e espiritual dos muçulmanos da região, afirmando assim a independência religiosa da Andaluzia. A Espanha islâmica chega, então, a seu apogeu e Córdoba se torna a capital cultural do Islã ocidental, tendo uma belíssima mesquita e, na biblioteca do califa, 40.000 volumes e muitos originais gregos.

De 755, data reconhecida como o nascimento político do Islã ocidental, a 1031, a Espanha muçulmana esteve sob o poder dos omíadas. Com a destituição do último califa omíada em 1031, derrotado pelas tropas de Al-Mansur, conquistador vindo do norte da África, acaba o califado da Espanha, dividido em vários emirados, chamados Reinos de Taifas, que, enfraquecidos por lutas fratricidas, foram vencidos pelos cristãos nas guerras de reconquista. Apesar de unificada pelas dinastias almorávida (1086-1147) e almôada (1147-1269), a Espanha muçulmana foi-se enfraquecendo com o avanço da reconquista cristã no século XIII, permanecendo apenas o reino nazarí de Granada, que em 1492 caiu sob as tropas de Fernando e Isabel, reis católicos de Castela e Aragão, encerrando quase 800 anos de domínio islâmico.

São próprios desse período a tolerância religiosa, a aproximação sociocultural de cristãos, judeus e muçulmanos, significativos avanços na economia, na filosofia, nas letras, nas artes e na cultura em geral. $\mathrm{O}$ ódio existente entre as dinastias abássida, em Bagdá, e omíada, em Córdoba, as diferenças de cultura e religião entre medievais latinos e árabes, entre cristãos, judeus e seguidores de Maomé não impedem que a grandeza e as conquistas culturais do Islã oriental cheguem à Espanha, onde se concentra a produção filosófica e científica do Islã ocidental. Comerciantes e peregrinos que anualmente vão 
a Meca trazem também idéias e manuscritos. Com a queda do califado em 1031, há transferência dos estudos para Toledo, para onde se deslocam filósofos, médicos, matemáticos e astrônomos.

As conquistas da ambiciosa política cultural dos abássidas chegam à Idade Média latina no movimento de mudança de domicílio, transferência dos estudos, translatio studiorum, do Oriente para o Ocidente, de Bagdá para Córdoba, cidade sob domínio árabe de 711 a 1236, quando retorna ao mundo cristão. No século X e nas primeiras três décadas do século XI, "a Andaluzia tornar-se-á um dos principais centros culturais do mundo medieval” (DE LIBERA, 1998, p. 143).

Viajando pelo Oriente, a Grécia e os países árabes em busca de manuscritos, trabalhando individualmente ou em equipe, em impérios persas, islâmicos ou cristãos, às vezes escrevendo comentários e obras próprias, os tradutores cristãos, judeus e árabes contribuem para mudanças radicais na Idade Média latina, com desdobramentos em todo o Ocidente até hoje. No século XII e na primeira metade do século XIII, continuando a translatio studiorum, Palermo, na Sicília, e a corte de Frederico II, em Nápoles, tornam-se importantes centros de tradução. Em Toledo, libertada do domínio árabe pelas tropas de Afonso VI de Castela, em 1085, o bispo francês Raimundo de Sauvetat (1125-1151) reúne uma equipe, na qual se destacam Domingos Gundissalino, Gerardo de Cremona e João de Espanha, que traduziu 92 obras do árabe para o latim, num importante trabalho de mudança cultural a partir do convívio com as obras científicas greco-árabes. Ao considerar completamente outra a situação cultural da Idade Média latina no final do século XII e no século seguinte, devido sobretudo à incorporação pelos vencedores cristãos da cultura que os muçulmanos levaram séculos para reunir, organizar e desenvolver, De Libera afirma que:

[...] se o Islã ocidental desabou [...] filosoficamente diante dos exércitos cristãos, ele conquistou, como outrora aconteceu com Grécia e Roma, o seu vencedor. À medida que o território muçulmano encolhia, a filosofia passava, por uma espécie de osmose, da terra do Islã para países da cristandade. A 'translação dos centros de estudo' continuava (1998, p. 146).

As traduções, às vezes acompanhadas de comentários, tornam possíveis o restabelecimento do convívio dos latinos com os originais gregos, numa época em que poucos conhecem essa língua, bem como a descoberta e o conhecimento das fontes árabes e judaicas. Graças a elas o Ocidente supera a incultura, o não-saber característico do período de decadência e queda do Império Romano e dos primeiros séculos da Idade Média, a escola renasce, se difunde, se afirma e aprofunda os estudos nos séculos XI a XIII, mestres e estudantes contam com textos em sua própria língua, um mundo diferente se descortina e começa a se realizar, e a universidade se afirma como obra de cultura, instituição por excelência do trabalho intelectual, da investigação e da formação.

Sem tradução não há vida intelectual, produção própria, e o mundo da cultura se enclausura, se estiola e desaparece, como lembra De Libera, ao afirmar que após a Idade Média: 
os mundos muçulmanos saíram parcialmente da história da filosofia, e a filosofia saiu parcialmente da história dos mundos muçulmanos quando, precisamente, deixou-se, segundo a bela frase de Alkindi, de 'fazer' a ciência estrangeira 'falar árabe', em suma, quando se deixou de traduzir. O segredo do Renascimento ocidental no século XV é o mesmo do 'renascimento no século XII'; é o de todos os renascimentos: a tradução (1998, p. 188).

Em outro deslocamento dos centros de saber e poder, a Gália, região atual da França, Bélgica e Suiça, substitui Grécia e Roma, Bagdá, no Iraque, Córdoba e Toledo na Espanha, e Nápoles na Itália, como novo centro de civilização e de cultivo do saber. A ciência, o estudo das sete artes liberais, a filosofia e a teologia, seguidas pelo direito e pela medicina, se instalam em Paris, para onde acorrem sábios, mestres e estudantes de todo o mundo cristão, cidade essa que alguns consideram o lugar do pecado e da perdição, e outros, a cidade santa, onde se sente a presença de Deus, os textos de filosofia e os livros sagrados são lidos e explicados com zelo.

Esse rico processo de fermentação, ebulição e sedimentação cultural que, em momentos, ritmos e intensidade diferentes, envolveu a Idade Média latina, possui, como vimos, vínculos estreitos com a sociedade, a história e as religiōes monoteístas: judaísmo, cristianismo e islamismo, que conferem ao livro um sentido fundamental. Torna possível, expressa e afirma outras realidades e dimensões das quais é inseparável, a começar pela expansão da escola a partir dos mosteiros ou abadias (escolas monásticas, monacais ou abaciais) no final do século IV, das paróquias (escolas paroquiais ou presbiterais) e, junto às catedrais das cidades mais importantes, escolas catedralícias, canônicas ou capitulares, porque dirigidas pelos cônegos da catedral, ou, ainda, episcopais, porque criadas e mantidas pelo bispo, em latim episcopus, do grego epíscopos, aquele que guarda, vigia, protege. Além da escola palatina, sob a direção de Alcuíno, algumas escolas catedralícias se destacaram pelo espírito investigativo, a criação intelectual e o brilho de seus mestres: Anselmo (1050-1117), em Laon, Guilherme de Champeaux (1070-1121) e Pedro Abelardo (1079-1142), em Paris, e vários mestres, em Chartres, no século XII. Nas escolas dos mosteiros, das catedrais e da corte se estudam as sete artes liberais e a Sagrada Escritura.

Pedro Abelardo, polêmico e brilhante mestre do século XII, o maior lógico de seu tempo, conhecido como "cavaleiro da dialética”, vence em debate público seu ilustre mestre Guilherme de Champeaux, da abadia dos cônegos agostinhos de São Vítor e depois bispo de Châlons de 1113 a 1121. Embora nessa época os latinos só conheçam poucos textos da lógica antiga, o magistério e escritos lógicos de Abelardo são o que houve de mais significativo na filosofia e na escola de seu tempo, contribuindo para o reconhecimento de Aristóteles como o filósofo por excelência, o aprimoramento e a afirmação da escolástica como filosofia e método e da teologia como ciência, ou saber que incorpora a dialética no estudo das questôes relativas a Deus. 
O termo escolástica vem de schola em latim, originário do grego skholé que signfica tempo livre, estudo, escola, atividade intelectual desinteressada, não ligada à utilidade. $\mathrm{Na}$ Idade Média latina, scholasticus é o mestre, o chefe dos estudos, o homem culto, versado nas sete artes liberais e nas questôes teológicas. A Escolástica é então a filosofia e a teologia constituídas e ensinadas nas escolas dos séculos X a XVI da Idade Média latina, caracterizadas por grandes sínteses e sistemas de pensamento voltados para a compreensão racional da fé. É ao mesmo tempo uma forma, um método de investigação, de cultivo da razão e de exposição do pensamento, com suas regras e suas exigências, e que envolve a lectio, a quaestio, a disputatio, como veremos, o estudo, a interrogação sobre o sentido dos termos, das palavras, das sentenças e dos textos, a dialética, a lógica, a arte de argumentar, os conceitos fundamentais com os quais procura explicar as questóes do conhecimento humano, do mundo das coisas, dos homens e da fé cristã. Para ela, "pensar é um ofício cujas leis são minuciosamente fixadas", diz Chenu (Apud LE GOFF, 1989, p. 74). No Renascimento, o termo foi usado em sentido pejorativo de discussões vazias de significado e estéreis, verbalismo.

Se o cristianismo é uma religião douta, se a revelação não é destituída de sentido e supõe uma adesão pessoal e esclarecida, cabe à razão buscar esse sentido e proporcionar aos homens os preâmbulos da fé, praeambula fidei, não de uma fé ingênua e cega, mas da fé que aspira ao entendimento, procura a inteligência, o auxílio do intelecto, fides quaerens intellectum, para a compreensão e a explicação racional, nos limites do possível, da doutrina cristã, da boa nova, do evangelho, euangélion. Sem o auxílio da razão, como se definir entre afirmações diferentes ou contrárias nos textos sacros entre uma que diz "sim" e outra que diz "não" sobre a mesma questão? Ao escrever o livro Sic et non, Sim e não, dialetizando afirmações divergentes e contraditórias, Abelardo insiste na necessidade imperiosa do recurso à razão para esclarecer as questōes e ajudar a evangelização. Embora distinta da fé e da religião, a razão com elas mantém vínculos estreitos e profundos, se faz iluminada pela fé, ratio fide illustrata, que lhe põe novos problemas a serem pensados e estabelece balizas que orientam a reflexão, o trabalho intelectual, a investigação e o ensino.

Apesar de muito poucas, as obras gregas conhecidas pelos medievais latinos da primeira metade do século XII criam condiçôes para o aparecimento de mestres mais bem preparados. Aos poucos eles tomam consciência - de me presumens, disse Abelardo - do sentido e da importância de seu fazer intelectual e do ofício que exercem para a cidade, a comuna, a sociedade, a Cristandade, a Igreja, o Império cristão, a criação do clima intelectual e do espírito que move as escolas urbanas, a universidade nascente, para a constituição e a afirmação de significativas diferenças no pensamento e de novas dimensões na docência.

A redescoberta da quase totalidade das obras de Aristóteles e sua tradução na segunda metade do século XII e no século XIII foram fundamentais para a compreensão racional do mundo e do homem, independente das verdades da fé, diferentemente das concepçōes vigentes, que, mesmo usando a dialética, ainda se situavam na esfera da religião; para 
pensar a revelação que procura esclarecer-se pela razão, e para a constituição e a afirmação da teologia como ciência das coisas divinas. Se a obra do estagirita à primeira vista deixava o cristão diante de problemas complicados, relativos à imortalidade da alma humana, à criação ou à eternidade do mundo, entre outros, por outro lado, era tudo o de que grande parte dos mestres, limitados pela forma dialógica do texto platônico, precisavam para exercer seu oficio nas escolas. Nada melhor para formar a mente dos estudantes do que um texto lógico, ordenado, próprio para o ensino e cuja leitura se faz ela mesma formativa, não tanto pelo conteúdo, mas pela forma: estudo dos termos, conceitos e distinções fundamentais, argumentos, silogismos, demonstração da verdade do que foi dito. Não por acaso os textos de Aristóteles são cada vez mais copiados, lidos e ensinados, apesar das sucessivas proibições de sua leitura e ensino que acabaram ficando letra morta.

A grande expansão da escola, do trabalho dos copistas e dos tradutores propicia comentários mais amplos e profundos de textos religiosos e profanos que são lidos, postos em questão, submetidos ao debate, num evidente movimento de afirmação da razão, da dialética, na leitura dos textos, na constituição de novas formas de docência, de aula e produção de obras que decorrem do trabalho com as sentenças, os conceitos, os argumentos, as teses, no ato de ensinar e aprender. O rigor, a profundidade e a riqueza dos comentários e questóes variam, dependendo dos conhecimentos e da maturidade dos que comentam os textos e debatem as questōes, sobressaindo-se de forma exemplar a figura de Tomás Aquino (1225-1274), o grande mestre do século XIII.

A criação e a rápida expansão das novas ordens religiosas, franciscanos e dominicanos, vivendo no meio urbano, dedicadas à pregação da palavra de Deus e à renovação espiritual do cristianismo, o fascínio exercido pelas ordens mendicantes e seu modo de viver a pobreza evangélica, atraindo leigos e eclesiásticos do clero secular para os conventos, a boa formação e o brilho de seus mestres que parecem ofuscar os outros professores e retirar-lhes alunos, a acusação de que esses mestres não seguem os regulamentos e os costumes da corporação e de que os dominicanos privilegiam a discussão de textos e questôes da obra de Aristóteles, em detrimento dos autores consagrados, de certo modo desestabilizam a universidade. Os mestres apegados à tradição e acostumados à autoridade do texto bíblico e dos Padres da Igreja, em especial de Santo Agostinho, e a não incorporarem em suas aulas as contribuições da dialética e os conceitos fundamentais de Aristóteles, sentem-se inseguros e ameaçados, vendo em tudo isso um grande perigo, novidade demais, para não dizer abuso inadmissível. A reação, dura e às vezes violenta, aliada a acusaçōes variadas, não demorou a vir à tona, criando um clima tenso no meio universitário e levando as autoridades eclesiásticas, inclusive alguns papas, a intervirem ora em favor de um ou de outro grupo. As proibições de leitura e ensino da filosofia e da obra de Aristóteles estão ligadas também a esses embates e reaçôes que opóem, de um lado, grande parte de mestres franciscanos e do clero secular, e de outro, mestres dominicanos. 
Nesse contexto cultural e escolar rico, fecundo, em processo de secularização crescente e nesse ambiente tenso e às vezes agressivo, os textos são estudados, lidos, ouvidos, comentados, discutidos, refutados e recriados com dedicação e interesse, nas aulas das escolas anexas às catedrais de importantes centros de criação e transmissão do saber, como Chartres e Paris, e sobretudo nas universidades. Com a redescoberta, a tradução para o latim, a leitura e os comentários das obras de Aristóteles, em especial a metafísica, os escritos lógicos e sobre o mundo natural tornaram-se logo objeto de interesse especial e de importantes debates. De tesouro a ser guardado, como ainda acontecia no século IX, o saber passa a ser trabalhado e interrogado como algo vivo e provocante da inteligência de mestres e estudantes, em lectiones e disputationes cada vez mais concorridas.

Embora continuem, e até hoje guardem seu sentido, as lectiones, nos séculos XII e XIII não eram meras leituras dos textos. Devido sobretudo às dificuldades de acesso aos manuscritos, caros e inicialmente copiados nos mosteiros, o ensino nas escolas da Idade Média latina, incluindo a universidade, inicia-se com a lectio, leitura do texto, acompanhada dos comentários do professor e das anotaçóes feitas pelos alunos. Realizada de manhã pelos mestres, essa atividade era repetida e explicitada à tarde pelos bacharéis ou repetitores. Na teologia o texto básico era geralmente livro de sentenças, sobretudo Quattuor libri sententiarum, escrito entre 1155 e 1157, por Pedro Lombardo (1100-1160), bispo de Paris, lido e comentado nas universidades medievais ainda no final do século XV, objeto de aproximadamente 250 outras obras que o comentam.

O verbo latino legere significa colher, recolher, escolher, percorrer, ler. Daí o sentido do substantivo lectio: ato de colher, recolher, escolher, selecionar, ler; leitura, lição, o que se lê, texto. Na própria etimologia da palavra lectio está presente o sentido de ato de escolher, selecionar o que deve ser lido, comentado, explicado e entendido. O texto é percorrido, explorado em busca do sentido dos termos; os conceitos, as teses e os argumentos são submetidos a uma interrogação cuidadosa que revela o que aí se encontra, o que está dito. Mestres e estudantes colhem, recolhem o sentido e o percurso do pensamento, da razão. Além de transcrever e traduzir, os medievais se preocupam sobretudo em ler, comentar e discutir os textos, as idéias e as questōes dos antigos, incorporando-as em suas aulas, demonstrações e obras. E, ao fazê-lo diante dos alunos, o professor mostra as palavras ou termos principais e seu sentido, a articulação das frases ou premissas, as idéias, os conceitos e as partes mais importantes e difíceis do texto que exigem atenção especial do leitor. A lectio, portanto, nem de longe se assemelha a um ritual, a uma repetição de sons, palavras e frases. Pelo contrário, é um ato de criação, de pensamento, um ato do intelecto.

Eram lidos e comentados textos ou citações de autores selecionados, considerados autoridades, auctoritates, pois traziam as questôes fundamentais, os princípios gerais e basilares do saber numa determinada área, sobretudo na filosofia e na teologia. Merecedores de respeito, por isso mesmo precisavam ser discutidos e pensados, não podendo ser simplesmente aceitos e repetidos, sem se perguntar qual o seu sentido. 
O termo latino auctoritas vem de auctor que significa aquele que faz nascer, crescer, funda, fundador, instituidor; o que gera pessoas, e não seres biológicos, o que instiga, aconselha, promove, é responsável por; autor, escritor, mestre, conselheiro, fiador. Daí o sentido de auctoritas: realização, consumação, instigação, autoridade para definir a lei e fazer a justiça, poder em sentido pleno, exemplo, garantia, fiança, responsabilidade, respeito, reputação, peso da pessoa, da palavra e da ação. Não tem, portanto, um conteúdo jurídico, e somente se exerce pelo peso da pessoa, da palavra e da ação, sendo diferente e em termos de moralidade superior a potestas, poder de execução e de administração de pessoas e coisas. O sentido da expressão latina é diferente do que em português, sobretudo numa sociedade autoritária como a nossa que entende por autoridade o poder de mando, de se fazer obedecer; superioridade de quem ocupa um cargo, função, ou tem status que lhe confere o poder de, em princípio, fazer o que quiser. Por sua vez auctor vem do verbo augere, que está na origem desses dois substantivos e significa fazer crescer, aumentar, elevar a honra, a dignidade, engrandecer, produzir, proteger. A auctoritas, portanto, não vem de cima para baixo nem define o sentido do texto, dos conceitos, argumentos e teses, mas surge e se afirma no movimento da reflexão. Não nega nem dispensa a discussão, pelo contrário, faz nascer, crescer, instiga, promove, enriquece, avaliza, garante o debate e o pensamento. Tudo isso nos leva a repensar a questão da autoridade em educação.

Desde os primeiros séculos do cristianismo, a definição e o aprofundamento das questōes teológicas, em especial a relação entre ciência e fé, razão e revelação, liberdade e graça, a Encarnação e a Trindade, envolveram acirradas discussões filosóficas e teológicas, em que auctoritas e ratio, autoridade e razão, tradição e pensamento se fizeram inseparáveis. $\mathrm{Na}$ escolástica, sobretudo, as concepçōes das auctoritates não eram seguidas cegamente, mas submetidas à interrogação racional, mesmo porque em geral são conflitantes e às vezes contraditórias, o que exige a atividade do intelecto para, nas condições e limites da época, interrogar o sentido dos termos, os conceitos, os argumentos, as doutrinas e chegar à verdade daquilo que é, do mundo e do homem, o que não é possível sem o recurso à razão, ao rigor e às sutilezas da lógica. Num sentido diferente e oposto do que vimos, o argumento de autoridade é, hoje, freqüentemente usado de forma ideológica e autoritária, numa referência pejorativa à Idade Média como século das trevas, do obscurantismo, num completo desconhecimento de quase cem anos de pesquisas de grandes medievalistas. Sem se acomodarem, os intelectuais da Idade Média latina vão ao encontro das autoridades por eles citadas para compreenderem as questôes relativas ao mundo, às coisas, ao homem, à sociedade e à fé. Le Goff cita Honório de Autun, professor em Chartres, pensando a relação entre autoridade e razão, fé e razão: "Não há outra autoridade senão a verdade comprovada pela razão. O que a autoridade nos ensina a crer, a razão nos confirma por suas provas; o que a autoridade evidente da Escritura proclama, a razão discursiva comprova" (1989, p. 51) .

Em sua oralidade, as lectiones estão na origem dos comentários como formas literárias, e estes na origem das sumas como obras de elaboração pessoal e sistemática, sínteses 
intelectualmente amadurecidas, abrangendo a totalidade das questôes fundamentais numa determinada área, sobretudo na teologia. Em latim, summa significa resumo, totalidade, a parte mais elevada, importante, essencial. Tomás de Aquino escreveu a Suma contra os gentios e a Suma teológica.

Apesar dos avanços e da crescente profundidade característicos do ensino dos séculos XII e XIII, a lectio mantém a sua importância, sua condição de ponto de partida e de prática fundante e usual à qual sempre se recorre nas escolas da Idade Média latina, incluindo a universidade. Da lectio surge a quaestio, questão, dificuldade que se torna objeto de debate, de confronto de teses e argumentos, disputatio, substantivo que significa cálculo, disputa, discussão, controvérsia, debate. Em vez de simples questão, surge uma autêntica quaestio disputata, muito valorizada nos séculos XII e XIII. Essas três expressões latinas provêm dos verbos quaerere, que significa buscar, procurar, aspirar a, esforçar-se, empenhar-se, indagar, perguntar, interrogar, e disputare, cujo sentido é examinar, expor os argumentos de uma causa, discutir, debater, argumentar, disputar.

A disputatio podia ser ordinária ou solene. A disputatio ordinaria, conforme o costume, regular ou usual, ocorria a cada sete ou 14 dias e versava sobre um tema previamente definido pelo mestre que propunha o debate, a ser conduzido por seu bacharel e anunciado com antecedência, para conhecimento dos interessados. Posta a quaestio, explicado seu sentido e importância, o debate transcorria com a apresentação das objeções, dos argumentos contrários à tese enunciada, envolvendo a participação efetiva e apaixonada de mestres e estudantes. Dependendo da questão e do mestre responsável pela disputatio, outros intelectuais, residentes na cidade ou aí de passagem certamente se fariam presentes ao debate. $\mathrm{O}$ bacharel, com a ajuda de seu mestre, respondia às objeções apresentadas pelos presentes. Em virtude da natureza mesma da disputatio, o que aí acontecia em parte escapava ao controle dos responsáveis, mas, tendo em vista os argumentos contrários e os favoráveis à tese proposta, as respostas dadas e as anotações dos taquígrafos, o mestre organizava e ordenava tudo num texto lógico e, após um ou mais dias, apresentava sua resposta à questão, conhecida como determinatio, na qual contemplava e respondia a todas as objeções e elaborava os argumentos em defesa de sua tese.

No exercício de seu magistério, Tomás de Aquino dirigiu disputas sobre a verdade, o mal, a alma, a potência e o ato, as criaturas espirituais, entre outros temas. $\mathrm{O}$ problema da verdade, De veritate, foi discutido em 29 quaestionmes disputatae que se desdobram em 253 artigos, sendo a de número 11 dedicada à discussão do ensino, De magistro, em quatro artigos. Essas questôes foram disputadas na Faculdade de Teologia da Universidade de Paris, de 1256 a 1259. O magistério e a obra de Tomás de Aquino, o grande mestre da universidade medieval, são exemplares no trabalho de investigar, ensinar, comentar, compreender e explicar os textos sagrados, os escritos dos Padres da Igreja, dos árabes Avicena e Averróis, sobretudo a obra e o pensamento de Aristóteles, 
bem como de realizar disputationes, expressão máxima do ensino, da docência, da filosofia e da teologia escolásticas dos séculos XII e XIII, e da natureza mesma da universidade.

Vejamos como se desenvolvia a quaestio disputata, conduzida por Tomás de Aquino, tomando como exemplo a estrutura do primeiro artigo de seu De magistro, resultante de aula do jovem mestre-regente em Paris. O texto inicia-se com o enunciado da tese sob a forma de controvérsia, "se o homem, ou somente Deus, pode ensinar e ser dito mestre", seguido da quaestio "parece que só Deus ensina e pode ser dito mestre", cujo sentido não coincide com o que será defendido por Tomás de Aquino. Seguem-se os argumentos favoráveis à tese de que somente Deus ensina e pode ser chamado de mestre, posição essa contrária ao pensamento do autor. Precedidos de um Sed contra, "mas ao contrário", vêm os argumentos contrários à tese enunciada e, portanto, no sentido do que Tomás defende. Ouvidos os argumentos favoráveis e os contrários à formulação da tese, em seu ofício de mestre, Tomás de Aquino apresenta sua determinação, determinatio, posição ou solução pessoal da questão, que se inicia com respondeo, respondo. Por último, responde a cada um dos argumentos ou autoridades favoráveis à forma como a questão foi enunciada e contrária à posição por ele defendida. Muitas vezes essas questões não trazem uma resposta acabada ao que está em discussão, deixando em aberto a possibilidade de se continuar pensando, investigando. Esses debates aguçam o espírito, avivam o domínio da dialética (lógica), das sutilezas da argumentação. "Assim se desenvolve a escolástica, mestra do rigor, estimuladora do pensamento original na obediência às leis da razão" (LE GOFF, p. 78). Essa é uma forma de docência que hoje assustaria mesmo professores e estudantes interessados e bem preparados.

Nas disputationes sollemnes ou disputationes publicae, também chamadas de disputationes de quolibet e realizadas duas vezes por ano, por ocasião do Natal e da Páscoa, os participantes interessados no debate rigoroso e profundo podiam pôr questôes sobre qualquer assunto e apresentar objeções difíceis e embaraçosas. Havia ainda opositores que gostariam de desmoralizar, diante de todos, o mestre que dirigia esse tipo de disputatio, levando-o a cair em contradição. Somente mestres muito qualificados e seguros de si tinham condições e coragem de realizar essas disputas, diante de toda a universidade e de outros interessados, sujeitando-se a debater questóes imprevisíveis e temas polêmicos. O risco era grande, sobretudo na Universidade de Paris, que no século XIII reunia os professores e os estudantes mais brilhantes e inquietos, provenientes de todo o mundo cristão. No período de 1256 a 1259, em que produziu as 29 quaaestiones disputatae sobre a verdade, De veritate, e alguns opúsculos, Tomás de Aquino redigiu 12 questões quodlibéticas.

Sua fidelidade às idéias presentes em cada citação e o respeito aos autores, auctoritates, privilegiando a posição dos adversários no enunciado da tese, apresentando primeiro os argumentos dos quais diverge, que, no artigo primeiro do De magistro, chegam a 18 , contra apenas seis no sentido da tese por ele defendida, embora nem sempre idêntica 
a sua posição; a preocupação e o cuidado em não influenciar o ouvinte ou o leitor para que aceite sua tese ou determinação, e a atenção em responder a cada um dos opositores, mostram a dignidade, a grandeza humana e intelectual de Tomás de Aquino. Certamente nós, professores, temos muito a aprender com esse grande mestre.

Sem dúvida, da Idade Média latina aos nossos dias avançamos muito em termos de ensino e pesquisa - e não poderia ser diferente, afinal setecentos anos de história não são de pouca monta -, mas o fizemos sobretudo em termos tecnológicos, práticos, pragmáticos e operacionais, ao mesmo tempo em que abandonamos questóes fundamentais como a finalidade, o sentido e as exigências de nossa condição humana, a primazia da coisa pública, do que é coletivo em todos os aspectos e momentos da existência. Estamos perdendo a dimensão humana, intelectual e universal da docência, a sensibilidade, a imaginação e a reflexão, o valor fundamental do livro, da leitura, do trabalho com os conceitos e argumentos, a razão como auctoritas por excelência e, então, perdemos a auctoritas para ensinar e formar. O magistério toma o caminho da profissionalidade, da técnica, da formalidade burocrática, do preenchimento das exigências cartoriais no ensino e na pesquisa, do produtivismo desvairado, das aparências, da busca do sucesso, escorregando muitas vezes no individualismo e na prepotência.

Com Sócrates aprendemos o princípio fundamental da docência, segundo o qual não há aprendizagem sem que o estudante apreenda o sentido do que leu ou foi-lhe ensinado, sem que compreenda e dê seu assentimento aos conceitos, juízos, argumentos, demonstraçōes e teses constitutivas do texto lido, da aula ou conferência, tornando-se capaz de demonstrar a veracidade, ou de contestar a fragilidade e os equívocos do afirmado, das idéias, dos métodos e descobertas em exame, bem como a superficialidade e banalidade da prática, desmontando o que parece se impor como verdadeiro e bom.

$\mathrm{Na}$ escola medieval não há laboratórios, nem tecnologias de ensino e multimídia, mas se dá grande valor ao livro, sem o qual não se concebe o trabalho intelectual. Os textos e aqueles que os escrevem são considerados auctoritates, pois ajudam mestres e estudantes a crescerem. Apesar da situação histórico-social, todas as quaestiones passam pelo exame da razão, são submetidas oralmente à apreciação racional dos mestres e estudantes que participam das disputationes, bem como dos que irão ler o texto escrito e transcrito para uso dos interessados nessas questōes.

Ao negar a questão do sentido da universidade e da docência e privilegiar a instrumentalidade, hoje poucos procuram fazer do aluno um estudante; boa parte dos docentes abraça, adere e louva idéias, teorias e livros que estão mais para ficções, fantasmas, do que para realidade, mais para simplificaçôes e banalizações do que para o estudo e a leitura rigorosa e crítica, inerentes ao trabalho intelectual. Tangido por condiçôes adversas e interesses vários, particulares, contingentes e mutáveis, pelo mercado, a tecnologia e a mídia o docente muitas vezes esquece que seu ofício é fazer aprender, ensinar, instruir, docere e, para tanto, precisa a cada momento se fazer doctus 
sábio, douto, com discernimento e, ao mesmo tempo, doctor, mestre, aquele que realmente ensina, trabalha para constituir como realidade viva e interrogante a doctrina, o ensino, a instrução, a educação, a cultura, a teoria, o método, e para formar os estudantes nessa e por essa "con-vivência" com o saber, a cultura, a formação.

\begin{tabular}{|c|c|}
\hline Expressões latinas e gregas & Pronúncia \\
\hline auctor - auctoritas - plural auctoritates & áuctor - auctóritas - auctoritátes \\
\hline augere & augére \\
\hline commentari & $\begin{array}{l}\text { com-mentári - pronunciar sempre as duas } \\
\text { consoantes }\end{array}$ \\
\hline determinatio - disputatio & determinácio - disputácio \\
\hline disputationes sollemnes ou publicae & disputaciónes sol-lémnes ou públice \\
\hline disputationes de quolibet & disputaciónes de qüólibet \\
\hline docere - doctrina - doctor - doctus & docére - doctrína - dóctor - dóctus \\
\hline episcopus & epíscopus \\
\hline euangélion (grego) & euanguélion \\
\hline fides quaerens intellectum & fídes qüérens intel-léctum \\
\hline legere - lectio - plural lectiones, & légere - léc-cio - lec-ciónes \\
\hline monachus & mónakus \\
\hline palatium - potestas & palácium - potéstas \\
\hline praeambula fidei & preámbula fídei \\
\hline quaerere - quaestio disputata & qüérere - qüestio disputata \\
\hline quaestiones disputatae & quaestiónes disputáte \\
\hline Quattuor libri sententiarum & Qüátuor líbri sentenciárum \\
\hline ratio fide illustrata & rácio fíde il-lustráta \\
\hline regulae, plural de regula - respondeo & régule - régula - respóndeo \\
\hline schola - scholasticus - summa & skóla - skolásticus - sum-ma \\
\hline translatio studii - translatio studiorum & translácio studii - translácio studiórum \\
\hline universitas magistrorum et scholarium & univérsitas magistrórum et skolárium \\
\hline
\end{tabular}




\section{Referências}

BOEHNER, Philotheus; GILSON, Etienne. História da filosofia cristã. 5. ed. Petrópolis: Vozes, 1991. BRÉHIER, Émile. História da filosofia: Idade Média e Renascimento. São Paulo: Mestre Jou, 1978 , v. 3.

DE LIBERA, Alain. A filosofia medieval. São Paulo: Loyola, 1998. . Pensar na Idade Média. São Paulo: Ed. 34, 1999.

DURKHEIM, Émile. A evolução pedagógica. Porto Alegre: Artes Médicas, 1995.

HADOT, Pierre. O que é filosofia antiga?. São Paulo: Loyola, 1999.

LE GOFF, Jacques. Os intelectuais na Idade Média. 2. ed. São Paulo: Brasiliense, 1989.

MARROU, Henri-Irinée. História da educação na Antiguidade. São Paulo: Herder, 1966.

NASCIMENTO, Carlos Arthur Ribeiro do. Santo Tomás de Aquino: o boi mudo da Sicília. 2. ed. São Paulo: Educ, 2003.

PEREIRA, Maria Helena da Rocha. Estudos de história da cultura clássica: cultura romana. 3. ed. Lisboa: Fundação Calouste Gunbekian, 2002, v. 2.

PIEPER, Josef. Filosofia medieval y mundo moderno. 2. ed. Madrid: Rialpa, 1979.

PLATONE. Tutte le opere. Edizioni integrali con testo greco a fronte. A cura di Enrico V. Maltese. Roma: Newton, 1997, v. 1 e 4.

STEENBERGHEN, Fernand van. História da filosofia: período cristão. Lisboa: Gradiva, s.d.

TOMÁS DE AQUINO. De magistro - Sobre o mestre: questôes discutidas sobre a verdade, XI. Edição bilíngüe. Trad., introd. e notas de Maurílio J. O. Camello. Disponível em: http://www.lo.unisal.br/nova/graduacao/filosofia/murilo/Tom\%E1s\% 20de\%20Aquino.doc. Acesso em: 14 jun. 2007.

TORRELL, Jean-Pierre. Santo Tomás de Aquino: sua pessoa e obra. São Paulo: Loyola, 1999. ULMANN, Reinholdo Aloysio. A universidade medieval. 2. ed. rev. aum. Porto Alegre: EDIPUCRS, 2000.

VAZ, Henrique Cláudio de Lima. Escritos de filosofia I: problemas de fronteira. São Paulo: Loyola, 1986. . Cultura e universidade. Petrópolis: Vozes, 1966.

WOLFF, Francis. Três figuras do discípulo na filosofia antiga. Discurso. São Paulo, n. 22, p. 123152, 1993. 


\section{M. Coêlho}

\section{The genesis of university teaching}

Abstract

This article discusses the constitution of teaching in the Latin middle age, inseparable from the socioeconomic and political transformations, from the transference of Greco-Arabic knowledge, the scholar and cultural revivals, the work of translators and copyist monks and from the intrinsic connection among research, formation and teaching in the recently created university. By recovering etymology and pronunciation of terms, the author discusses the Scholasticism, philosophy and teaching method whereby teaching affirms itself on the act of reading, explaining and commenting on texts, submitting concepts, arguments and theses to the scrutiny of reason, and bringing up questions for public discussions, in which truth does not depend upon the authority of someone, but on what was said. Rediscovered and translated, Aristotle's works arise like a threat to some masters, but also to others, like everything that they might need to practice their profession: a logical text, deeply formative. Thus, the medieval university and its masters can help us to rethink and recreate teaching today.

Keywords: Teaching. Copyists. Translators. Transference of knowledge. Authority. Reason.

\section{La genèse de l'enseignement universitaire}

\section{Résumé}

Cet article discute la constitution de l'enseignement dans le temps médiéval latin, inséparable des transformations socio-économiques et politiques, des transferts du savoir gréco-arabe, des renaissances culturelles et scolaires, du travail de moines copistes et traducteurs, de la liaison intrinsèque entre recherche, formation et enseignement dans l'université récemment créée. Récupérant étymologie et prononciation des termes, il discute la Scolastique, philosophie et méthode d'enseignement par laquelle l'enseignement s'affirme dans l'acte de lire, expliquer, commenter les textes, soumettre des concepts, arguments et thèses au scrutin de la raison, mettre des questions en discussions publiques dans lesquelles la vérité ne dépend pas de l'autorité de qui dit, mais de ce qui a été dit. Redécouvertes et traduites, les cuvres d'Aristote apparaissent comme menace pour quelques maîtres, mais pour d'autres, cela était tout ce dont ils avaient besoin pour exercer leur profession : un texte logique, profondément formatif. Ainsi l'université médiévale et ses maîtres peuvent nous aider à repenser et recréer l'enseignement aujourd'hui.

Mots clefs : Enseignement. Copistes. Traducteurs. Transferts du savoir. Autorité. Raison.

\section{La génesis de la docencia universitaria}

Resumen

El artículo discute la constitución de la docencia, en el medieno latino, inseparable de las transformaciones socioeconómicas y políticas, de las transferencias del saber grecoárabe, de los renascimientos cultural y escolar, del trabajo de monjes copistas y traductores, de la conexión intrinseca entre investigación, formación y enseñanza en la universidad recién creada. Recuperando etimología y pronunciación de los términos, discute la escolástica, filosofía y método de enseñanza en que la docencia se afirma en el acto de leer, explicar, comentar los textos, someter conceptos, argumentos y tesis a la prueba de la razón, poner cuestiones en discusiones públicas as en las cuales la verdad no depende de la autoridad de quién la dice, pero de lo que fue dicho. Redescubiertas y traducidas, las obras de Aristóteles surgen como amenaza para algunos mestres, pero para otros era todo lo que necesitaban para ejercer su oficio: un texto lógico, profundamente formativo. Asi la universidad medieval y sus mestres pueden ayudarnos a repensar y recriar la docencia hoy.

Palabras-clave: Docencia. Copistas. Traductores. Tranferencias del saber. Autoridad. Razón.

Recebido: 15.01.2008 - Aceito: 21.06.2008 